\title{
The Relation Between Capital and Labor as a Basis for the Distribution of the Added Value
}

\author{
Zivko Bergant \\ College for Accounting and Finance, Ljubljana, Slovenia
}

Email address:

zivko.bergant@siol.net

To cite this article:

Zivko Bergant. The Relation Between Capital and Labor as a Basis for the Distribution of the Added Value. International Journal of Science, Technology and Society. Vol. 7, No. 3, 2019, pp. 50-55. doi: 10.11648/j.ijsts.20190703.12

Received: March 26, 2019; Accepted: April 29, 2019; Published: August 29, 2019

\begin{abstract}
The author discusses the basis of distributing the added value in the view of social responsibility. He finds the distribution of added value as a crucial challenge in following the principles of social responsibility. The study shows the considering of intellectual capital as a prerequisite for the distribution of the surplus added value according the social responsibility of the company. The findings significantly change and improve the understanding of social responsibility in the area of distribution and the structure of the added value in the company. The basic expression of social responsibility is the contribution to the welfare of the whole society. This contribution should be understand in its broadest sense. The main starting point for distribution of added value is stakeholders' contribution to managing the business risk. The author developed a new category surplus value added by subtraction of minimal wages and opportunity cost of equity. On this basis the author proposes a new statement of surplus added value, compared with actual accounting profit and loss statement. Statement of surplus added value should become the basis expression of social responsibility of the company and its orientation to sustainable development.
\end{abstract}

Keywords: Social Responsibility, Added Value Law, Distribution of Added Value, Value Added Statement, Stakeholders

\section{Introduction}

The growing difference between rich and poor requires deeply understanding and adequate solutions [1, 2]. The article deals on the field of economic from the view of social responsibility which is a precondition of sustainably development. There are many authors who claim the stakeholder value as the right business goal of the company instead of the shareholder value [3]. It became apparent that the company can no longer exist for profit and narrow purposes only [4].

In the following we shall treat capitalism as the dominant socio-economic system. In this regard, we will emphasize, in particular the distribution that is an area that the modern political economy completely ignored. Today in economic sciences, there are mostly post-Keynesian and neoclassical theories and combinations of both. The approach is characterized by the assumptions about the concept of values that prevent both synthesis and a proper debate about the economy. This is expressed in a spontaneous conflict, where no side is left out of arguments and counter arguments. This conflict has always been present in capitalism and has only been exacerbated recently. This reflects the theoretical emptiness of the important field of recent political economy, and the very notion of value is that which can, at the expense of explicit explication, begin to fill this theoretical void and to devise the catastrophic situation in which our society found itself [5].

The purpose of the article is to find adequate solution for the distribution of added value among stakeholders. Therefore, the main question is how to find the basis of distributing the added value concerning the principle of social responsibility to avoid the increase of further differentiation between rich and poor people. To achieve this goal the structure of intellectual capital and the structure of the added value will be analyzed.

First, we shall define the main categories, especially surplus added value. Second, we shall show the elements of intellectual capital. Third, we shall define the stakeholders of the company ${ }^{1}$ and adequate added value structure. Fourth, we

1 E. g. one of important stakeholders is the state [9]. 
shall define companies' stakeholders regarding their risk exposure. At the end we shall propose the form of valueadded statement and compare it with profit and loss statement. In conclusion we shall propose a new surplus value-added statement as an important accounting information. In this process we shall use different methods as: description, classification, compilation, and comparison to achieve the goal of the paper.

\section{Understanding Social Responsibility and Added Value}

Social responsibility is defined by authors in many ways. Here, in particular, we will emphasize two aspects:

1. Added value law is not a part of legislation, because it is a social law. It is discovered and explained by Bergant [6]. From the added value law point of view, social responsibility can be defined as the responsibility of individuals and organizational systems of all forms and levels in the creation and distributing of surplus added value, that is, in increasing the welfare of the whole society. Only surplus added value increases the social well-being ${ }^{2}$.

Such a definition considers the coherence and interdependence of all individuals and organizational systems and requires awareness of their impact on the creation and sharing of added value. It also embodies the principle of ethical action, since unethical action increases the tendency toward the breakdown of organizational systems and reduces the well-being of society.

In this definition, we understand the added value in its widest sense, which in addition to accounting and expanded point of view [8], includes forms of added value that cannot be fully evaluated (e.g. contributions to culture, art, well-being and health). Such an understanding of added value is the true motive for measuring the performance of a business.

2. In terms of the socio-economic system, social responsibility is reflected in the design of such a system, which increases the efficiency of society in generating added value and takes into account the interests of stakeholders in its distribution. The holder of this type of social responsibility is, in principle, the whole society, but the greatest part of responsibility lies on individuals who have impact on the formation and changes of the socio-economic system. These individuals are professionals and politicians. They are obliged to create conditions for improving or changing the existing socio-economic systems from the sustainable development point of view.

2 Social well-being in broader sense encompasses different aspects: sustainable development, distribution of household income, distribution of opportunities, subjective well-being, and distribution of world wealth, economic security, and trust in institutions [7].

\section{Capital and Labor from the Added Value Point of View}

For a long time, it is obvious that labor is the most important producer, and considering broadly, it is the intellectual property of the company. Without it (invisible assets) one cannot explain the huge differences between market and accounting values of the company [10].

Invisible assets are dealt with in different ways in the literature. Some of authors treat them with an evaluation of:

a) Intangible assets,

b) Intellectual capital,

c) Human resources [9].

Human resources may be treated as capacity and considered as intellectual property. This is shown in Figure 1.

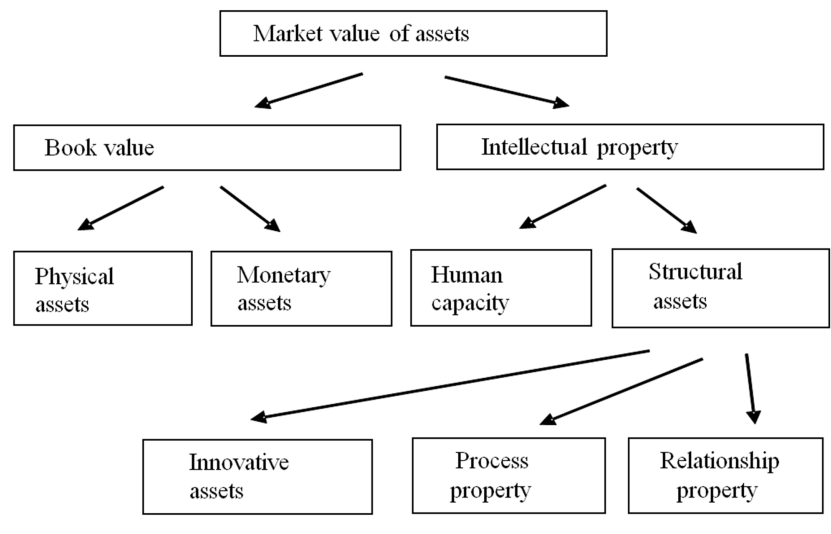

Source: Adapted from: Joia [11].

Figure 1. Elements of intellectual property.

After simplifying intellectual property as a labor and treating it as a means of production and as the fundamental creator of added value, its source is undoubtedly the intellectual capital.

It is necessary to take this fact into account when determining the contribution to the added value, because the ratio between the contribution of work and equity (which is in fact the result of the past work) is crucial in the process of the added value distribution.

The current legislation allocates the generated profit to the owners of equity, which is in direct contradiction with previous findings and represents an embedded instrument of conflicts and an increase in income inequalities among the population. This reduces the efficiency of the entire society and increases the tendency to decompose the system.

As a natural starting point for the definition of the stakeholder participation in added value, is its contribution to managing the business risk. Any different starting point means the possibility of exploiting at least one stakeholder group and increasing dissatisfaction. A well-known saying that the greed is the driving force of the capitalist development is purely misleading, because the greed (gaining participation in added value which is disproportionate to the contribution to its creation) is the driving force of disintegration. 
On the basis of the above, one can conclude that the social responsibility of all involved is reflected in a well-organized system of creating and distributing added value. From a financial perspective, this is reflected in the value-added statement $(V A S)$. The value added $(V A)$ in companies has been known in world literature since 1954 and in practice since 1975 [12]. Today, $V A S$ is an integral part of the annual reports, which are complementary to the financial statements, in many international corporations. In Brazil and Nigeria, $V A S$ is a mandatory component of the financial statements $[13,14]$.

\section{Surplus Added Value Law}

By strictly observing the added value law, we defined a new category, namely a surplus added value (SVA) [6]. This category is obtained by subtraction of minimal wages ${ }^{3}(\mathrm{MW})$ and opportunity costs of equity $(O C E)$. This is illustrated by the following equation:

$$
S V A=V A-M W-O C E
$$

or:

$$
S V A=E p a r t+S H p a r t+I+T+R S V A E+R S V A O(2)
$$

Surplus added value is therefore composed of:

1) Employee participation (including remuneration and management bonuses - Epart),

2) Shareholder participation (SHpart),

3) Financing costs $(I)$,

4) State taxes $(T)$,

5) Retained $S V A$, which is allocated to the employees (RSVAE),

6) Retained $S V A$, which is allocated to the owners of equity (RSVAO).

The surplus added value, thus defined, has some important advantages over the traditional added value, namely it:

1) Means the consistent derivation of a substantively indisputable definition of added value (as a new value);

2) Means a quantity that is (or is supposed to be) the subject of distribution to the stakeholders;

3) Constitutes the basis for equal treatment of all stakeholders, thereby removing inequality of labor and capital in the existing socioeconomic system;

4) Eliminates deceit and apparent justice about participation of employees in value added;

5) Means a more precise category compared to the known categories such as newly created value and income.

Equation 2 does not take into account the so-called "entrepreneurial rent", which means compensation to the founders of the company for their entrepreneurial idea and investment initiative. Such a motivational instrument is undoubtedly economically important for the development of the economy and society as a whole. It is not showed in

3 Minimal wages express minimal life costs of employees and are equal for all employees, including management. They are not (or better should not be) taxed. equation 2 because such a compensation was limited by a certain length of time, since even the legal protection of patents and licenses is limited to a maximum of 20 or even less years.

\section{Surplus Added-value Statement}

It is also important to define the surplus added value statement $(S A V S)$ on the above bases. Here we start from the following starting points:

a) The statement should indicate the sources (factors) of surplus value added during the accounting period;

b) The statement should be useful for a wider circle of interested people or organizations;

c) The statement should be useful for creating indicators and improving the organizational atmosphere;

d) The surplus added value statement is not a substitute for the profit and loss account, but a different view to the operating result; therefore, individual items are treated differently than in the income statement;

e) Inside the material costs the minimum wages are considered as an expression of the estimated labor force consumption in the business;

f) Opportunity costs of equity $(O C E)$ are considered inside the material costs as well;

g) The statement shows the generation of surplus added value (its sources) and its distribution as well;

h) The most important starting point for $S A V S$ is the equality of stakeholders, not only in participating in surplus added value, but also in terms of risk management cooperation. This means that the traditional concept of management is no longer appropriate, since the current life requires a more democratic approach.

Based on the above starting points, a practical example of surplus added value statement $(S A V S)$ can be formulated compared to the profit and loss account $(P \& L)$ which is shown in Table 1.

Table 1 contains the following assumptions:

1) There are 100 employees;

2) Minimal wage per capita is $€ 800,00$;

3) Total capital is $€ 5.000,00$;

4) Opportunity cost of capital is $2,5 \%$;

5) Profit tax is $15 \%$

6) Retained profit is allocated to employees and active owners in the ratio between the amount of rewards to active owners and the amount of salaries of other employees (assumption is $1: 2$ );

7) For the sake of simplification, it is assumed that all employees are active co-governors;

8) For the sake of simplification, there is no differentiation between gross and net amounts of remuneration (the difference is, in principle, the state's participation in surplus added value).

In Table 1, the surplus added value was allocated to:

1) Non-active stakeholders, who carry a small part of the risk and whose common feature is that they are directly 
or indirectly affected by better or worse performance from the operation of the group, but cannot directly influence the business decisions; but they have a possibility to control the participation of:

a) The financiers;

b) The state;

c) The shareholders and portfolio investors;

2) Managing (active) stakeholders who, in addition to bearing the risk, also contribute to risk management, in particular employees, shareholders (active equity holders) and management, or others (for example, strategic business partners who contractually take part of the risk by participating in a joint venture outcome).

It is important to emphasize that the distinction between managers and non-managers, changes with the development of co-governance. At the same time, this also presents one of the motives for development of co-governance, which should therefore not be too rigidly administratively limited.

Table 1 shows in particular:

1) Added value $(€ 3,308)$ is significantly higher than profit, as it also includes labor costs and financing costs;

2) Surplus added value ( $€ 3,103)$ is equal to added value, reduced by minimum wages and capital costs;

3) After deduction of dividend tax and rewards to management, the remaining net profit in the amount of $€ 300$ remains retained;

4) Surplus added value is allocated to non-managers (€ 951) and managers (€ 2,152);

5) Financiers (financing costs), non-active owners (small shareholders) and state taxes are considered among the non-active stakeholders;

6) The largest share in surplus added value is allocated to employees (EUR 1,820), which is the result of the assumption of their active participation; otherwise, this proportion would of course be lower than the amount shown among non-managers;

7) Retained earnings belong both to employees and to active owners in the assumed proportion of their receipts.

Table 1. Surplus value-added statement and profit and loss statement In $€ 1,000$.

\begin{tabular}{|c|c|c|c|}
\hline & ITEMS & P\&L & SAVS \\
\hline & A. GENERATING PROFIT AND ADDED VALUE & & \\
\hline 1 & Sales & 9.100 & 9.100 \\
\hline 2 & Material costs & 4.900 & 4.900 \\
\hline 3 & Amortization and depreciation & 1.280 & 1.280 \\
\hline 4 & Labor costs & 1.900 & \\
\hline 5 & Financing costs & 400 & \\
\hline 6 & Costs of minimal wages & & 80 \\
\hline 7 & Opportunity cost of equity & & 125 \\
\hline 8 & Profit & 1.008 & \\
\hline 9 & Added value $(4+5+8)$ & & 3.308 \\
\hline 10 & Surplus added value $(9-6-7)$ & & 3.103 \\
\hline & B. DISTRIBUTION OF PROFIT AND $S A V$ & & \\
\hline 11 & Tax & 151 & \\
\hline 12 & Net profit $(8-11)$ & 857 & \\
\hline 13 & Net profit for dividends & 525 & \\
\hline 14 & Net profit for management awards & 32 & \\
\hline 15 & Retained net profit & 300 & \\
\hline 16 & $S A V$ for financier (interest) $I$ & & 400 \\
\hline 17 & $S A V$ for non-active shareholders dividends & & 400 \\
\hline 18 & $S A V$ for the state (taxes) $T$ & & 151 \\
\hline 19 & SAV for non-active stakeholders $(16+17+18)$ & & 951 \\
\hline 20 & $S A V$ for employees & & 1.820 \\
\hline 21 & $S A V$ for management awards & & 32 \\
\hline 22 & Retained $S A V$ for employees & & 200 \\
\hline 23 & Retained $S A V$ for active shareholders & & 100 \\
\hline 24 & SAV for managing stakeholders $(20+21+22+23)$ & & 2.152 \\
\hline 25 & SAV $(19+24)=10$ & & 3.103 \\
\hline
\end{tabular}

In line with the idea of expanded added value, a broader aspect of surplus added value is defined, which is important for presenting achievements from the social responsibility point of view. Therefore, it is intended to present this part in the notes to the excessive value-added statement, similar to the need for explanations to the income statement.

From the comparison between the two statements, in Table 1 one can summarize particular the following:

1) SAVS (together with explanations) takes into account the equality of stakeholders in accordance with the added value law and contributes to the disclosure of the corporate social responsibility, orientated to sustainable development;

2) $S A V S$ does not mean only a different view of the company's profit or loss, but it also shows that profit is not a basic information about the business from the point of view of the social responsibility, and even less in terms of sustainable development; profit as a category in $S A V S$ simply does not exist;

3) SAVS takes over a leading role before the profit and loss account; therefore, it can no longer be regarded as only complementary information to the income statement; 
4) SAVS represents a useful basis for analyzing the efficiency and effectiveness of the operations, since the surplus added value replaces the profit as the underlying business goal;

5) SAVS means important information, especially for stakeholders of the organization who bear the risk of operations;

6) $S A V S$ can be important information for investors and business partners, especially in terms of long-term and stable operations;

7) $S A V S$ is also an important information for the concerned wider public, especially in terms of social responsibility; in particular, information of the distribution of surplus added value is important;

8) Table 1 otherwise shows the connectivity of the surplus added value with the income statement, which is completely unnecessary for the preparation of SAVS. This does not mean that $P \& L$ would not be prepared, because it contains (in terms of a different view of business) useful supplementary information. This applies in particular to the transitional period until the implementation of the surplus value added takes effect;

9) $S A V S$ should become an integral part of a comprehensive reporting.

SAVS has some disadvantages, in particular the following ones:

1) In a comparative assessment (benchmarking) or within an activity, comparability is worse, if there are differences in starting points for determining the minimum wage or assessing the opportunity costs of the financial capital;

2) For the same reasons, SAVS may be less suitable for statistical processing at the state level and for comparisons between different countries.

Problems with comparability can be solved satisfactorily with an appropriate standardized statement, which will undoubtedly be the subject of development over a longer period of time in the future.

Due to the urgency of the various criteria, the process of allocation of the surplus added value to the stakeholders in accordance with its structure in Equation 2, should be carried out in the individual steps that follow in the appropriate order. Therefore, there is the process of the surplus added value distribution, which includes the following procedures:

1) The identification stakeholders' participation in accordance with applicable regulations (e.g. tax obligations);

2) The determination of the stakeholders' participation in accordance with the accepted contracts or agreements (e.g. interest);

3) The definition of the required amount of retained surplus added value in accordance with the development plan, which must also take into account the company' capital adequacy;

4) The definition of the amount of wages in the planned (agreed) extent (whereby management is included in accordance with the adopted internal rules);
5) The definition of the amount of surplus added value for non-active owners of financial capital in accordance with the defined dividend policy adopted by the active owners together with the employees' representatives;

6) The identification of possible residual surplus of added value, which can be further distributed to employees and management as a reward for successful operations.

7) The determination of the share of employees and share of financial capital owners in retained surplus added value.

The most sensitive parts of the process are undoubtedly the points 3, 4 and 5. The order shown is principled, but in practice it depends on the power ratio between management, active owners, and employees. Therefore, the criteria used to define their participation, can vary.

\section{Main Findings}

From the sustainable development point of view, it is of primary importance to define the retained surplus added value, which is linked both to development opportunities and the ability of a long-term borrowing.

The decision on this is undisputedly connected with the corresponding policy wages, including the motivation system, which should also be development oriented. The decision for the inactive owners' participation (e.g. dividends) is only the result of the definition of development funds needed and the appropriate amount of wages.

The discussed process of sharing surplus added value is set in principle, but it enables organizations to implement concrete solutions in accordance with the added value law, that is, with the equality of stakeholders while ensuring the sustainable development.

This is reflected below in the summary of receipts of employees (and also of management members). These are:

1) Minimum wages, taking into account difficult work conditions;

2) Basic salaries according to the general act of the organization (which also usually takes into account the variable part of the salary according to the contribution of the individual);

3) The reward from the residual surplus value after the deduction of the retained amount of surplus added value (in this frame, it is also a possibility for rewarding the management with regard to the business success of the company).

The owners of the capital receive:

1) The compensation for the opportunity cost of capital;

2) Dividends in accordance with the defined dividend policy considering the surplus added value.

\section{Conclusion}

We defined the contribution to managing business risk as a crucial base for distributing the surplus added value among the stakeholders according the principle of social responsibility. It means that the efficiency and effectiveness 
of models about all other fields of social responsibility from economic point of view depend on satisfactorily distribution of surplus added value. The main reason is the achievement of satisfaction of stakeholders regarding the equality of their participation in added value. For this purpose the surplus added value statement is originally created and proposed as an important accounting information.

The findings in the article are limited because of theoretical approach, therefore further research is needed. Such an approach namely requires huge changes in socioeconomic system. The process should start with deepening academic research about all needed changes and their consequences in legal, economic, social and tax system. It means also that changes could not be implemented without political will on all levels.

\section{References}

[1] Piketty, T. (2014). Capital in the Twenty-First Century. USA: The Fellows of Harvard College.

[2] Bajo, C. S., Roelants B. (2011). Capital and the Debt Trap. Basingstoke: Palgrave Macmillan.

[3] Brennan, L. (2019). Corporations must rethink capitalism to heal society's wounds. Financial Times, 28. January 2019.

[4] Tlhaby, P. (2014). Discovery Ltd.: Integrated Annual Report 2014. (Retrieved: January, 2016). https://www.discovery.co.za/discovery_coza/web/linked_cont ent/pdfs/investor_relations/discovery_annual_integrated_repor t_2014.pdf.

[5] Dolinar, A., Božič, J. (2014). A short history of value theory. Razpotja, No. 17/2014, pp. 7-10. (Retrieved: December, 2016). (In Slovene) https://www.dlib.si/details/URN:NBN:SI:DOCZTG2HV27/?euapi $=1 \&$ query $=\% 27$ keywords $\% 3$ ddolinar + an $\%$ c5\%bee $\% 27 \&$ pageSize $=25$.
[6] Bergant, Ž. (2017). Appropriate consideration of value added law as a precondition of social responsibility. International conference about social responsibility. Maribor: IRDO, 28. 11. $2017 . \quad$ http://www.irdo.si/irdo2017/referati/plenarnabergant.pdf. (Retrieved: January, 2019).

[7] Stiglitz, E., Joseph, Fitoussi, Jean-Paul, Durand, M. (2018b). For Good Measure: Advancing Research on Well-Being Metrics Beyond GDP. Pariz: OECD Publishing. (Retrieved: December, 2018). http://www.oecd.org/publications/for-goodmeasure-9789264307278-en.htm.

[8] Mook, L. I. (2007). The Expanded Value Added Statement. Doctoral dissertation. University of Toronto. (Retrieved: January, 2016). http://home.oise.utoronto.ca/ /schugurensky/Mook_Thesis.pd f.

[9] Mazzucato, M. (2013). The Entrepreneurial State. USA: Public affairs.

[10] Milost, F. (2012). Računovodsko obravnavanje nevidnih poslovnih prvin organizacije. Zbornik 2. konference o notranjem poročanju. (In Slovene). Ljubljana: Inštitut za poslovodno računovodstvo.

[11] Joia, L. A. (2000). Measuring intangible corporate assets. Journal of Intellectual Capital No. 1/2000, pp. 68-84. (Retrieved: December, 2016). http://app.ebape.fgv.br/comum/arq/JIC.pdf.

[12] Suojanen, W. W. (1954). Accounting theory and the large corporation. The Accounting Review, July, 1954, pp. 618-629.

[13] Machado, A. V., Márcio, Macedo, M. A., da Silva, Machado, R., Márcia (2016). Analysis of the Relevance of Information. Content of the Value Added statement in the Brazilian Capital Markets.

http://papers.ssrn.com/sol3/papers.cfm?abstract_id=2601211. (Retrieved: October, 2016).

[14] Donleavy, D., G. (2015). Usefulness unfulfilled: a performance review of value added statements. International Journal of Critical Accounting. No. 4/2015, pp. 315-334. 